\title{
PENGARUH REGULASI DIRI SISWA TERHADAP PRESTASI BELAJAR SISWA KELAS VIII PADA MATA PELAJARAN IPS
}

\author{
Chientya Annisa Rahman Putrie \\ Universitas Panca Sakti, Bekasi, Indonesia \\ Chientya2725@gmail.com
}

\begin{abstract}
Received: 12 Desember 2020 Penelitian ini bertujuan untuk mengetahui Pengaruh Regulasi Diri Revised: 19 Januari 2021 Terhadap Prestasi Belajar Siswa Kelas VIII Pada Mata Pelajaran IPS. Jenis Accepted: 13 Maret 2020 penelitian yang dilakukan adalah kuantitatif . Populasi targetnya adalah seluruh siswa kelas VIII yang berjumlah 233 siswa. Metode dalam penelitian ini adalah survey. Teknik pengambilan sampel yang digunakan adalah Slovin sebanyak 147 siswa. Instrumen yang digunakan adalah angket dan wawancara untuk mengetahui kemampuan regulasi diri siswa. Hasil penelitian menunjukkan adanya pengaruh regulasi diri terhadap prestasi belajar siswa kelas VIII. Penelitian ini menunjukkan bahwa regulasi diri siswa dapat meningkatkan prestasi belajar yang didapatkan oelh masing-masing siswa dalam pembelajran. Uji persyaratan data yang digunakan adalah Uji Normalitas dengan metode Uji Kolmogrov Smirnov dan Uji regresi yang digunakan adalah Uji t. Uji yang digunakan memperolah hasil analisis $\mathrm{t}$ hit $=64,461$ dan $\mathrm{p}$-value $=0,000 / 2=0,000<$ 0,05 atau Ho ditolak. Maka terdapat pengaruh positif regulasi diri terhadap prestasi belajar siswa kelas VIII pada mata pelajaran IPS.

Keywords: Regulasi Diri; Prestasi Belajar
\end{abstract}

(*) Corresponding Author: $\quad$ Putrie, chientya2725@gmail.com, +62 81324679391.

How to Cite: Putrie, C. A. R. (2021). Pengaruh Regulasi Diri Siswa Terhadap Prestasi Belajar Siswa Kelas VIII Pada Mata Pelajaran IPS. Research and Development Journal of Education, 7 (1), 136-145.

\section{INTRODUCTION}

Pendidikan merupakan kebutuhan mendasar untuk meningkatkan suatu negara, bahkan suatu kehidupan tidak dapat dipisahkan dengan pendidikan, kualitas suatu bangsa, ditentukan oleh kualitas pendidikan di negara tersebut. Indonesia merupakan negara yang sedang berkembang dimana negara ini membutuhkan sumber daya yang berkualitas, dengan adanya sumber daya yang berkualitas manusia diharapkan memiliki keterampilan dan kemampuan untuk menciptakan hal baru demi majunya kualitas pendidikan. Pendidikan dipercaya sebagai sarana pencetak perubahan, dan dari pendidikanlah sebagian perilaku manusia, baik maupun buruk itu berasal. Bangsa Indonesia menaruh harapan yang sangat besar terhadap tenaga pendidik dalam perkembangan bangsa ini. Tenaga pendidik diharapkan mampu untuk membentuk generasi yang cerdas dan mampu memajukan bangsa, berbagai upaya dilakukan untuk meningkatkan mutu pendidikan di sekolah, antara lain dengan memperbaiki kualitas belajar mengajar.

Belajar mengajar disekolah merupakan serangkaian kegiatan yang sudah terencana dan dilakukan secara sadar, dengan adanya perencanaan proses pembelajaran diharapkan akan memberikan perubahan besar dalam pola hidup manusia, perubahan itu tidak hanya dengan penambahan ilmu pengetahuan, tetapi juga berbentuk kecakapan, keterampilan, sikap, minat, dan penyesuaian diri. Guru sebagai pendidik mampu memenuhi harapan dalam membawa materi dan siswa sebagai peserta didik yang menerima ilmu 
pengetahuan, salah satu upaya untuk memenuhi harapan tersebut adalah melalui proses pembelajaran yang dilakukan disekolah.

Proses pembelajaran disekolah dapat dikatakan berhasil jika dilihat dari prestasi belajar yang didapatkan siswa selama mengikuti proses pembelajaran (Vhalery, 2019), keberhasilan tersebut dapat dinilai dengan tes hasil belajar yang dilakukan secara berkelanjutan. Tentunya sebagai pendidik, orang tua maupun sekolah pun berharap setiap peserta didiknya memperoleh prestasi yang baik dan tinggi. Remaja awal sebagai peserta didik seharusnya meraih prestasi yang setinggi-tingginya, ia harus mampu meregulasi dirinya untuk mengarah ke hal yang positif demi cita-cita yang mereka impikan dan menjadi pribadi yang baik. Motivasi yyang timbul dari dalam dirinya untuk meraih prestasi gemilang dan tidak mudah menyerah dengan hal yang tidak sesuai dengan apa yang ingin dicapainya, karena ketuntasan dari prestasi belajar ditentukan jika siswa berhasil mencapai nilai minimum Kriteria Ketuntasan Minimum (KKM) yang berdasarkan kebijakan sekolah, apabila prestasi belajar siswa rendah ini bisa menjadi penghambat dalam pencapaian tujuan pendidikan.

Berdasarkan observasi yang penulis lakukan pada bulan Februari - Maret 2020, diketahui prestasi belajar mata pelajaran IPS kelas VIII dari tiga tahun terakhir belum optimal, dalam artian terdapat beberapa siswa yang belum mampu untuk mencapai Kriteria Ketuntasan Minimal (KKM) yang di tentukan oleh sekolah yaitu 74, seperti yang dipaparkan di dalam tabel di bawah ini.

Tabel. 1

Nilai Rata - rata Semester II Mata Pelajaran IPS Kelas VIII

\begin{tabular}{ccccccc}
\hline \multirow{2}{*}{ Tahun } & $\begin{array}{c}\text { Jumlah } \\
\text { Siswa }\end{array}$ & $\begin{array}{c}\text { Nilai Rata- } \\
\text { rata IPS }\end{array}$ & $\begin{array}{c}\text { Siswa Yang } \\
\text { Tuntas }\end{array}$ & $\begin{array}{c}\text { KETUNTASAN } \\
\text { Siswa Yang } \\
\text { Belum Tuntas }\end{array}$ & $\%$ \\
\hline $2016-2017$ & 72 & 62,21 & 40 & $55 \%$ & 32 & $45 \%$ \\
$2017-2018$ & 93 & 66,67 & 48 & $51 \%$ & 45 & $49 \%$ \\
$2018-2019$ & 216 & 63,02 & 102 & $50 \%$ & 114 & $50 \%$ \\
\hline Sumber: Waka Kurikulum & & & & &
\end{tabular}

Berdasarkan tabel di atas dapat dilihat masih banyak siswa kelas VIII yang mendapatkan prestasi belajar dibawah 74 , dalam artian tidak memenuhi Kriteria Ketuntasan Minimal (KKM) yang telah di tentukan oleh sekolah. Siswa dapat dikatakan tuntas secara individu jika memenuhi KKM yang telah di tentukan oleh sekolah. Menurut Badan Standar Nasional Pendidikan (BNSP) menyatakan bahwa suatu kelas dapat disebut tuntas jika presentase ketuntasan siswa itu minimum 75\%. Pada tahun pelajaran 20182019 dapat kita lihat bahwa dari 216 siswa yang mendapatkan nilai dibawah nilai ketuntasan minimal (KKM) ada sebanyak $50 \%$ berdasarkan hal tersebut, terlihat bahwa tingkat prestasi belajar IPS siswa kelas VIII tergolong belum mencapai KKM.

Jika dilihat dari hasil presentase di atas menimbulkan faktor yang dapat mempengaruhi, baik dari internal (dalam diri) siswa ataupun eksternal (di luar diri) siswa. Faktor internal yaitu yang ada di dalam diri siswa yaitu dari kecerdasan, intelegensi, perhatian, minat, bakat motivasi, kematangan, kesiapan dan kelelahan. Faktor eksternal (luar diri) siswa terdiri dari faktor lingkungan sosial, yaitu interaksi dengan guru, staff sekolah, organisasi, teman sebaya, keluarga dan masyarakat sekitar serta lingkungan non sosial, seperti sarana dan prasarana sekolah, alat-alat belajar, dan juga waktu belajar yang tersedia di sekolah.

Berdasarkan hasil wawancara yang penulis lakukan pada bulan Februari - Maret 2020 dengan beberapa orang siswa kelas VIII, bahwa salah satu faktor internal yang di duga menyebabkan rendahnya prestasi belajar siswa kelas VIII. Seperti halnya beberapa siswa yang sering menunda untuk mengerjakan tugas, siswa tidak memperhatikan ketika 
pembelajaran dikelas. Siswa cenderung lebih banyak bermain gadget ketika di luar lingkungan sekolah dan bermain dengan teman sebayanya sehingga setelah melakukan aktifitas tersebut siswa merasa lelah, dan akibatnya timbullah rasa malas untuk melakukan kewajiban sebagai siswa yaitu belajar. Hal itu membuat waktu terbuang siasia sehingga berdampak pada nilai akademik yang di peroleh siswa oleh karena itu dapat di lihat dari masalah di atas kemampuan siswa untuk mengontrol prilaku mereka sendiri belum maksimal.

Berdasarkan latar belakang masalah yang peneliti jelaskan diatas, maka peneliti mengambil judul untuk melakukan penelitian dengan judul "Pengaruh Regulasi Diri Siswa Terhadap Prestasi Belajar Siswa Kelas VIII Pada Mata Pelajaran IPS".

\section{LITERATURE REVIEW}

\section{Regulasi Diri}

\section{a. Pengertian Regulasi Diri}

Zimmerman dan Schunk (Annisa, 2017:4) mengatakan bahwa regulasi diri (self-regulation) merupakan proses dimana individu secara sistematis mengarahkan pikiran- pikiran, perasaan- perasaan, dan tindakan-tindakan untuk pencapaian tujuan. Untuk mencapai tujuan yang diinginkan setiap siswa mereka harus mengarahkan pikiran - pikiran, dan melakukan tindakan yang mereka inginkan. Berdasarkan pendapat diatas, dapat disimpulkan bahwa regulasi diri adalah kemampuan seseorang dalam mengendalikan diri mereka sendiri apa yang ingin mereka capai disekolah tergantung diri mereka masing- masing karena ini memerlukan tindakan - tindakan untuk mendapatkan hasil belajar selama disekolah yang ingin mereka capai, siswa yang dapat dikatakan berhasil jika seseorang siswa itu sendiri memiliki prestasi belajar disekolah yang terus meningkat.

\section{b. Faktor-faktor yang mempengaruhi Regulasi Diri}

Menurut Bandura (Rizqiyah, 2016:23) terdapat faktor yang mempengaruhi regulasi diri, yaitu :

1) Faktor eksternal Memberi standar untuk mengontrol tingkah laku. Kondisi tersebut mempengaruhi masing-masing diri untuk berinteraksi pada lingkunan sekitar, membentuk standar evaluasi diri seseorang melalui orang tua dan guru, dan baik buruk perilaku mereka ketika mereka berada disekolah maupun diluar sekolah.

2) Faktor Internal

Observasi diri (self-observation). seseorang harus mampu memonitor diri mereka sendiri baik atau tidaknya seseorang dilihat dari bagaimana dia berperilaku dan berpenampilan karena seseorang cenderung memilih sendiri bagaimana mereka berperilaku.

\section{c. Karakteristik Regulasi Diri}

Menurut Montalvo (Risa 2017:24) mengemukakan karakteristik siswa yang memiliki keterampilan regulasi diri antara lain yaitu :

1) Terbiasa dalam strategi kognitif (pengulangan, elaborasi, dan organisasi) yang membantu mereka dalam berkomunikasi. 
2) Mengetahui bagaimana perencanaan, pengontrol, dan pengarahan proses dalam memcapai tujuan yang diinginkan.

3) Melihat dari kemapuan yang tinggi dalam ruang lingkup motivasi dan emosi, seperti percaya diri yang tinggi, memiliki kemampuan untuk terus belajar, berfikir positif dan kemuan untuk mengembangkan kemampuan akademik.

4) Mampu memanfaatkan kondisi lingkungan dan berfikir untuk penyelesaian tugas belajar.

5) Menunjukan kemampuan dalam penyelesaan tugas akademik, dan struktur kelas.

\section{d. Komponen Regulasi Diri}

Baumeister dan Heatherton (Nugroho, 2018:28) mengemukakan bahwa regulasi diri memiliki 4 komponen, yaitu

1) Standar Kondisi ideal, cita-cita, tujuan maupun keadaan-keadaan yang ingin dicapai Tanpa adanya standar yang jelas dan terarah pada diri seorang siswa untuk mencapai sesuatu yang mereka inginkan, konsisten belajar akan berdampak pada terhambatnya pengembangan regulasi diri.

2) Monitoring, Perbandingan antara diri sendiri dengan standar yang ada. Untuk itu seseorang harus dapat mengontrol perilakunya. Kemampuan sesorang siswa dalam belajar dikelas dan menjaga atau mengontrol perilakunya agar tetap pada jalurnya. Kegagalan seseorang siswa untuk memonitor diri sendiri dapat menghambat regulasi diri.

3) Kekuatan regulasi diri Kekuatan regulasi diri atau tekad, kekuatan regulasi diri tidaklah mudah, maka dari itu seseorang siswa membutuhkan energi dan kekuatan. Proses regulasi diri bergantung pada kapasitas sumber daya atau energi di tiap seseorang dan sumber daya atau energi tersebut.

4) Motivasi, Motivasi seseorang untuk mencapai tujuan atau standar yang diinginkan. Dimana dalam prakteknya motivasi tersebut berperan untuk memotivasi seseorang agar dapat meregulasi dirinya demi tercapainya tujuan yang mereka inginkan, tanpa adanya motivasi dari dalam diri seseorang maupun dari luar diri siswa.

\section{e. Indikator Regulasi Diri}

Regulasi diri menurut Pintrich dalam Rachmah (Nurjana, 2019:17) memiliki 3 aspek. Masing-masing dari aspek tersebut memiliki indikator berdasarkan ciri-cirinya sebagai berikut:

1) Kemampuan metakognitif

2) Kemampuan mengontrol emoasional

3) Kemampuan mengatur perilaku

Berdasarkan penjelasan di atas maka indikator regulasi diri dapat dilihat dari masing-masing aspek regulasi diri. Dimana aspek regulasi diri meliputi metakognisi, motivasi, dan perilaku. Kemudian, pada masing-masing aspek tersebut memiliki indikator yang dapat diukur untuk mencapai keberhasilan regulasi diri dalam belajar peserta didik atau siswa.

\section{Prestasi Belajar}

\section{a. Pengertian Prestasi Belajar}

Menurut Syaiful Bahri Djamarah (Agustina, 2018:4) Prestasi belajar adalah hasil penilaian pendidikan tentang kemajuan siswa belajar siswa. Kemajuan siswa 
disekolah setelah melakukan kegiatan belajar dapat dilihat dari hasil penilaian di sekolah berupa prestasi yang didapatkannya.

Menurut Sudjana (Ramadhan, 2016:156) Prestasi belajar adalah mencerminkan tujuan pada tingkat tertentu yang berhasil dicapai oleh anak didik (siswa) yang dinyatakan dengan angka atau huruf. Keberhasilan peserta didik, dalam kegiatan belajar dapat dilihat dengan angka atau huruf yang diberikan guru.

Menurut Purwodarminta (Hendro, 2020:50) prestasi belajar berarti penguasaan pengetahuan atau keteramplan tertentu yang dikembangkan dari suat mata pelajaran yang umumnya ditunjukkan dengan nilai tes atau angka yang lebih diberikan oleh guru.

Menurut Syaodih (Fiqhan, 2019: 79) prestasi belajar merupakan segala perilaku yang dimiliki siswa sebagai akibat dari proses belajar yang ditempuhnya, meliputi semua akibat dari proses belajar yang berlangsung di sekolah atau di luar sekolah yang bersifat kognitif, afektif, maupun psikomotorik baik yang di sengaja ataupun yang tidak disengaja. Dimyati dan Mudjiono (Lutfi, 2018:62), prestasi belajar siswa berarti "tercapainya tujuan belajar siswa". Dengan demikian tercapainya tujuan intruksional, dan sekaligus tujuan belajar "perantara" bagi siswa. Prestasi belajar matematika siswa berarti tercapainya tujuan belajar matematika siswa.

\section{b. Faktor-faktor yang Mempengaruhi Prestasi Belajar}

Menurut Slameto (Arifayani, 2015:17) terdapat faktor-faktor yang mempengaruhi prestasi belajar yaitu:

1. Faktor internal, terdiri dari:

a) Kesehatan seseorang dapat berpengaruh terhadap prestasi belajar mereka di sekolah, sehat berarti mereka yang berada dalam keadaan baik. Kegiatan pembelajaran akan terganggu pada kondisi badan yang baik dimana mereka akan merasa lelah dalam belajar, mudah pusing, mudah mengantuk ataupun lainnya. Agar seseorang dapat belajar dengan baik mereka harus menjamin diri mereka sehat agar bisa mengikuti proses pembelajaran dengan baik dan fokus.

b) Kelelahan Jasmani disebabkan karena berlangsungnya suatu aktifitas atau pekerjaan dan timbullah kecenderungan untuk membaringkan tubuh, kelelahan dalam proses pembelajaran yang sedang siswa lakukan akan berpengaruh kepada tujuan yang akan mereka capai, siswa yang mudah lelah dan merasa tubuhnya lelah akan kurang maksimal dalam berpikir dan mengganggu proses belajar mengajar.

c) Kelelahan rohani disebabkan oleh terlalu banyaknya apa yang difikirkan dalam pikiran. Misal seorang siswa yang sedang mengikuti proses pembelajaran menjadi tidak fokus ke pembelajaran yang mereka sedang pelajari itu dikarenakan banyak pikiran yang mengganggu yang akibatnya menjadi tidak fokus dalam belajar ini akan berdampak pada prestasi yang didapat siswa nantinya.

d) Cacat tubuh adalah kondisi seseorang yang mempunyai keterbatasan bagian tubuh atau badan, keadaan ini akan mengganggu proses belajar mengajar. Siswa yang mengalami cacat tubuh ini akan mengganggu proses belajar nya. Misal kurangnya percaya diri dalam dirinya, menjadi minder dengan teman teman sebayanya. Jika hal ini terjadi pada seseorang mereka harus belajar pada lembaga pendidikan yang khusus dan harus ada alat 
yang membantu mereka agar mereka dapat belajar dengan baik sama dengan teman lainnya.

2. Faktor eksternal, terdiri dari:

a) Keluarga

Keluarga adalah lembaga pendidikan yang utama dan pertama. Cara orang tua mendidik anak berpengaruh terhadap prestasi anak. Tidak memperhatikan anaknya dalam mendidik menyebabkan anak tidak berhasil dalam berprestasi disekolah. Relasi antar keluarga adalah pola hubungan sedarah, relasi antar keluarga ini perlu dilakukan karena seorang siswa perlu adanya perhatian dari keluarganya baik itu cara mereka berpakaian, berpenampilan.

b) Sekolah

Metode mengajar adalah strategi yang akan dipakai dalam proses pembelajaran, metode belajar yang tidak menarik dan membosankan akan membuat anak kurang semangat untuk mau mempelajari sesuatu ini akan berdampak pada prestasi belajar. Proses belajar mengajar akan dapat efektif jika adanya hubungan baik antara guru dengan siswa, kurangnya relasi antara guru dengan siswa akan menyebabkan belajar siswa kurang optimal. Misal takutnya siswa ketika bertanya dikelas dikarenakan relasi antara gurunya kurang baik ini menyebabkan kesulitan belajar bagi siswa.

Relasi siswa dengan siswa terhadap displin sekolah perlu dilakukan, dengan adanya disiplin sekolah antar siswa ini akan membuat hubungan baik. Misalnya siswa menjaga kebersihan kelas yang menjadi ruangan mereka untuk belajar, dengan begitu ini akan membuat proses belajar menjadi lebih nyaman. Alat pelajaran sangat berhubungan erat dengan proses belajar disekolah dengan adanya alat pelajaran yang dimiliki guru dan siswa ini akan memudahkan dalam proses belajar mengajar.

Waktu sekolah adalah waktu terjadinya proses pembelajaran disekolah, waktu sekolah dapat mempengaruhi proses pembelajaran siswa. Siswa yang malas untuk bangun pagi akan membuat kurangnya konsentrasi dalam belajar, ini sangat mempengaruhi siswa dalam mendapatkan ilmu pengetahuan disekolah. Standar pelajaran di atas ukuran siswa dalam proses belajar akan menyulitkan jika apa yang seharusnya mereka pelajari mereka melebihi standar ukuran yang telah ditetapkan, ini menyulitkan siswa dalam memecahkan masalah dalam proses pembelajaran.

\section{METHODS}

Objek penelitian ini adalah siswa kelas VIII Mata Pelajaran IPS. Penelitian dilakukan pada bulan februari-maret 2020. Jenis penelitian adalah kuantitatif dengan metode survey. Populasi dari objek yang diteliti yaitu seluruh siswa kelas VIII sebanyak 233 siswa. Teknik penarikkan sampel yang menggunakan rumus Slovin sebanyak 147 siswa. Instrumen yang digunakan adalah angket atau kuesioner untuk mengetahui kemampuan regulasi diri siswa. Variable independen yang diteliti adalah variable $\mathrm{X}$ (Regulasi Diri) dan variabel dependen Y (Prestasi Belajar). Teknik analisa data yang dilakukan adalah Uji Validitas dan Reabilitas data menggunakan rumus korelasi Person Product Moment dan alpha Cronbach. selain itu peneliti juga menggunakan rumus 
Regresi Linier sederhana, Koefisien Korelasi Product Moment, serta Koefisien Determinan.

\section{RESULTS \& DISCUSSION}

\section{Pengolahan Data Hasil Penelitian}

Hasil tes regulasi diri pelajaran ilmu pengetahuan sosial pada siswa diperoleh dari sampel sebanyak 147 siswa, melalui tes yang berupa tes angket, wawancara. Tes yang diberikan untuk siswa sebanyak 26 butir pernyataan skala likert dengan rentang teoritik, perolehan skor responden telah diolah menjadi skor nilai dengan rentang skor dari 1 sampai dengan 5 setelah data terkumpul selanjutnya dilakukan pengolahan data menggunakan statistika deskriptif. Pada bagian ini penelitian mendeskripsikan hasil kuesioner 147 siswa, untuk memudahkan analisis data maka peneliti menyajikan hasil skor antar variabel.

Tabel. 2

Skor Regulasi Diri

\begin{tabular}{cll}
\hline No. & Ukuran Deskriptif & Nilai \\
\hline 1 & Mode & 62 \\
2 & Median & 66,00 \\
3 & Mean & 66,16 \\
4 & Simpangan Baku & 6,508 \\
5 & Varians & 42,357 \\
\hline \multicolumn{2}{l}{ Sumber: Peneliti (2020) }
\end{tabular}

Berdasarkan skor regulasi diri 147 responden siswa kelas VIII, diperoleh skor empirik terendah 52 dan skor empirik tertinggi 84, rentang skor 32, jumlah kelas 7 , rata-rata skor (mean) sebesar 66,16 simpangan baku 6,508, modus 62, median 66,00.

Tabel. 3

Skor Prestasi Belajar

\begin{tabular}{clc}
\hline No. & Ukuran Deskriptif & Nilai \\
\hline 1 & Mode & 56 \\
2 & Median & 56,00 \\
3 & Mean & 56,14 \\
4 & Simpangan Baku & 6,451 \\
5 & Varians & 41,616 \\
\hline \multicolumn{2}{l}{ Sumber: Peneliti (2020) }
\end{tabular}

Sumber: Peneliti (2020)

Berikut data hasil analisis dengan berdasarkan skor prestasi belajar IPS 147 responden siswa kelas VIII, diperoleh skor empirik terendah 42 dan skor empirik tertinggi 74 . Rentang skor 32, rata-rata skor (mean) sebesar 56,14, simpangan baku 6,451 , modus 56 , median 56,00 .

\section{Analisis Data}

\section{Uji Normalitas}

Dari data dibawah, diperoleh kolmogorov-smimovZ $Z$ sebesar 0,987, angka ini sama dengan hasil secara manual dan nilai Asymp. Sig. (2-tailed) sebesar 0,284 atau dapat ditulis sebagai nilai probabilitas $(p$-value $)=0,284>0,05$ atau Ho diterima. Dengan demikian, data regulasi diri berdistribusi Normal. 
Tabel. 4

Uji Normalitas Regulasi Diri

\begin{tabular}{llc}
\hline & & Regulasi Diri \\
\hline $\mathrm{N}$ & & 147 \\
Normal & Mean & 66.16 \\
Parameters & Std. Deviation & 6.508 \\
Most & Absolute & .081 \\
Extreme & Positive & .081 \\
Differences & Negative & -.056 \\
Kolmogorov-Smirnov Z & & .987 \\
Asymp. Sig. (2-tailed) & & .284 \\
Sumber: Peneliti (2020) &
\end{tabular}

Dari data dibawah, diperoleh kolmogrov-smimov Z sebesar 1,056, angka ini sama dengan hasil secara manual dan nilai Asymp. Sig. (2-tailed) sebesar 0,215 atau dapat ditulis nilai probabilitas $(p$-value $)=0,215>0,05$ atau $\mathrm{HO}$ diterima. Dengan demikian, data prestasi belajar IPS berdistribusi Normal.

Tabel. 5

Uji Normalitas Prestasi Belajar

\begin{tabular}{llc}
\hline & & Prestasi Belajar \\
\hline $\mathrm{N}$ & & 147 \\
Normal & Mean & 56.14 \\
Parameters & Std. Deviation & 6.451 \\
Most & Absolute & .087 \\
Extreme & Positive & .087 \\
Differences & Negative & -.055 \\
Kolmogorov-Smirnov Z & & 1.056 \\
Asymp. Sig. (2-tailed) & & .215 \\
\hline
\end{tabular}

Sumber: Peneliti (2020)

\section{Uji t}

Diperoleh persamaan regresi: $\mathrm{Y}=-8,325+0,974 \mathrm{X}$. Dari hasil analisis diperoleh $t_{\text {hit }}=64,461$ dan $p$-value $=0,000 / 2=0,000<0,05$ atau Ho ditolak. Dengan demikian, "regulasi diri berpengaruh positif terhadap prestasi belajar".

\section{Uji Hipotesis}

a. Hasil Analisis Uji Koefisiensi Korelasi dan Determinan $\left(\mathbf{R}^{2}\right)$

Tabel. 6

Model Summary

\begin{tabular}{|c|c|c|c|c|c|c|c|c|c|}
\hline \multirow[t]{2}{*}{ Model } & \multirow[t]{2}{*}{$\mathbf{R}$} & \multirow{2}{*}{$\begin{array}{c}\text { R } \\
\text { Squar } \\
\mathbf{e}\end{array}$} & \multirow{2}{*}{$\begin{array}{l}\text { Adjusted } \\
\text { R Square }\end{array}$} & \multirow{2}{*}{$\begin{array}{c}\text { Std. } \\
\text { Error of } \\
\text { the } \\
\text { Estimate }\end{array}$} & \multicolumn{5}{|c|}{ Change Statistics } \\
\hline & & & & & $\begin{array}{c}\text { R } \\
\text { Square } \\
\text { Change }\end{array}$ & F Change & df1 & df2 & $\begin{array}{c}\text { Sig. F } \\
\text { Change }\end{array}$ \\
\hline 1 & .983 & .966 & .966 & 1.189 & .966 & 4.155263 & 1 & 145 & .000 \\
\hline
\end{tabular}

Uji signifikansi koefisien korelasi diperoleh dari tabel model summary. Terlihat pada baris pertama koefisien korelasi $(\mathrm{r} x y)=0,983$ dan $\mathrm{F}$ hit $(\mathrm{F}$ change $)=4,155,263$, dengan $p$-value $=0,000<0,05$. Hal ini berarti Ho ditolak. Dengan demikian, koefisien korelasi $\mathrm{X}$ dan $\mathrm{Y}$ adalah berarti atau signifikan. Sedangkan koefisien determinasi dari tabel diatas terlihat pada baris ke-2, yaitu 
$\mathrm{R}$ Square $=0,966$ yang mengandung makna bahwa 96,6\% variasi variabel prestasi belajar IPS dapat dipengaruhi oleh regulasi diri.

\section{b. Hasil Analisis Regresi Linier Sederhana}

Tabel. 7

Anova Tabel

\begin{tabular}{|c|c|c|c|c|c|c|c|}
\hline & & & $\begin{array}{l}\text { Sum of } \\
\text { Squares }\end{array}$ & Df & $\begin{array}{l}\text { Mean } \\
\text { Square }\end{array}$ & F & Sig. \\
\hline $\begin{array}{l}\text { Prestasi } \\
\text { Belajar } \\
* \\
\text { Regulasi } \\
\text { Diri }\end{array}$ & $\begin{array}{l}\text { Between } \\
\text { Groups } \\
\text { Within Groups } \\
\text { Total }\end{array}$ & $\begin{array}{l}\text { (Combined) } \\
\text { Linearity } \\
\text { Deviation } \\
\text { From } \\
\text { Linearity }\end{array}$ & $\begin{array}{r}5.904 .236 \\
5.871 .124 \\
\\
33.112 \\
\\
\\
171.764 \\
6.076 .000\end{array}$ & $\begin{array}{r}27 \\
\\
118 \\
146\end{array}$ & $\begin{array}{r}210.866 \\
5.871 .124\end{array}$ & $\begin{array}{r}144.862 \\
40.333\end{array}$ & $\begin{array}{l}.000 \\
.000\end{array}$ \\
\hline
\end{tabular}

Sumber: Peneliti (2020)

Uji linearitas persamaan garis regresi diperoleh dari baris Deviation from linearity, yaitu $\mathrm{f}_{\text {hit }}(\mathrm{TC})=1,226$, dengan $p$-value $=0,0843>0,05$. Jadi Ho diterima atau persamaan regresi $\mathrm{Y}$ atas $\mathrm{X}$ adalah linear atau berupa garis linear.

\section{CONCLUSION}

Berdasarkan hasil penelitian yang dilakukan "Pengaruh Regulasi Diri Siswa Terhadap Prestasi Belajar Siswa Kelas VIII Mata Pelajaran IPS, maka penelitian ini disimpulkan sebagai berikut:

1. Hasil penelitian diketahui bahawa prestasi belajar siswa dipengaruhi oleh regulasi diri siswa, hal tersebut dapat dilihat dari perhitungan anova sederhana didapat nilai $\mathrm{p}$-value lebih kecil dari 0,05 dengan demikina Ho ditolah, regresi $\mathrm{Y}$ atau $\mathrm{X}$ adalah signifikan atau regulasi diri siswa berpengaruh terhadap prestasi belajar siswa, dengan persamaan $\mathrm{Y}=-8,325+0,974 \mathrm{X}$, demikian hipotesis penelitian didukung oleh data empiris.

Berdasarkan hasil uji persyarat data diperoleh hasil analisis $t_{\text {hit }}=64,461$ dan pvalue $=0,000 / 2=0,000<0,05$ atau Ho ditolak. Maka terdapat pengaruh positif regulasi diri terhadap prestasi belajar siswa kelas VIII pada mata pelajaran IPS.

\section{REFERENCES}

Agustina, Yenni dan Yuliana. (2018). Pengaruh Motivasi Dan Minat Belajar l.Terhadap Prestasi Belajar Siswa Di Smp Negeri 1 Peusangan Kabupaten Bireuen. JSEE Vol. VI, No. I, April 2018 ISSN:2354-6719 Jurnal Sains Ekonomi dan Edukasi.

Annisa, Anggrayani N. (2017). Hubungan Regulasi Diri (Self Regulation) Dalam Belajar Dengan Perencanaan Karir Pada Siswa Kelas XI Sma Negeri 1 Seputih Agung lampung. 
Arifayani, Yuli. (2015). Pengaruh Motivasi Belajar, Kemandirian Belajar, Lingkungan Teman Sebaya, Dan Perhatian Orang Tua Terhadap Prestasi Belajar Akuntansi Siswa Kelas X Smk Ypkk 1 Sleman.

Fiqhan, Ibnu Muslim. (2019). Pengaruh Minat dan Motivasi Belajar Terhadap Prestasi Belajar Ilmu Pengetahuan Sosial. Research and Development Journal Of Education. Vol. 5 No. 2 April 2019.

Hendro, Prasetyo. (2020). Peninkatan Konse Diri Terhadap Pestasi Belajar. ISSN 26571056. Research and Development Journal Of Education

Lutfi, Mohamad Nugraha. (2018). Pengaruh Persisntensi Diri Terhadap Prestasi Belajar Matematika Siswa Di SMP Al-Qalam. Research and Development Journal Of Education. Vol. 5 No. 1 Oktober 2018.

Nugroho, Rega Wibiyakto. (2018). Pengaruh Regulasi Diri Terhadap Ego Depletion Pada Mahasiswa.

Nurjanah, Siti. (2019). Hubungan Antara Regulasi Diri Dengan Prestasi Belajar Peserta Didik Pada Mata Pelajaran Akidah Akhlak Kelas VIII Mts N 2 Boyolali.

Rahayu, Risa. (2017). Hubungan Antara Regulasi Diri Dengan Prestasi Belajar Pada Siswa Kelas X SMA Negeri 1 Seputih Raman Lampung Tengah Tahun Ajaran 2016/2017.

Ramadhan, Restu Pangersa dan Hendri Winata. (2016). Prokrastinasi akademik menurunkan prestasi belajar siswa. Vol. 1 No. 1 Agustus 2016.

Rizqyah, Ni'matur. (2016). Pengaruh Strategi Regulasi Diri Dalam Belajar Dan Dukungan Sosial Orang Tua Terhadap Prestasi Belajar Siswa-Siswi Smp Hasanuddin Sepanjang Gondanglegi.

Vhalery, R. (2019). Pengaruh Komitmen Belajar dan Lingkungan Kampus Terhadap Hasil Belajar Matematika Ekonomi. Lembaran Ilmu Kependidikan, 48(1), 18-22. 